\title{
Study on combustion and emission characteristics of chars from low-temperature and fast pyrolysis of coals with TG-MS
}

\author{
Lei Liu, Zhiqiang Gong ${ }^{\dagger}$, Zhenbo Wang ${ }^{\dagger}$, Haoteng Zhang \\ State Key Laboratory of Heavy Oil, China University of Petroleum, Qingdao266580, China
}

\begin{abstract}
To achieve the clean and efficient utilization of low-rank coal, the combustion and pollutant emission characteristics of chars from low-temperature and fast pyrolysis in a horizontal tube furnace were investigated in a TG-MS analyzer. According to the results, the combustion characteristic of chars was poorer than its parent coals. The temperature range of gaseous product release had a good agreement with that of TGA weight loss. Gaseous products of samples with high content of volatile were released earlier. The $\mathrm{NO}$ and $\mathrm{NO}_{2}$ emissions of chars were lower than their parent coals. Coals of high rank (anthracite and sub-bituminous) released more $\mathrm{NO}$ and $\mathrm{NO}_{2}$ than low rank coals of lignite, so were chars from coals of different ranks. $\mathrm{SO}_{2}$ emissions of char samples were lower than parent coals and did not show obvious relationship with coal ranks.
\end{abstract}

Keywords: Char, Combustion, Emission, TG-MS

\section{Introduction}

Low-rank coal (lignite/sub-bituminous coal) accounted for more than $55 \%$ of coal reserves in China. In the past decades, Energy utilization efficiency was relatively low in China and low-rank coal was mainly combusted in power plants. How to achieve clean and efficient utilization of low-rank coal has become an important issue to be solved urgently.

In order to achieve the cascade utilization of low-rank coal, coal is to be pyrolysed during low temperature $\left(500^{\circ} \mathrm{C}-700^{\circ} \mathrm{C}\right)$ firstly and transformed to pyrolysis gases and char. The pyrolysis gases can be used as high-grade raw materials while the char can be combusted in power plants.

The incineration of circulating fluidized bed (CFB) boiler is an efficient and low pollution clean incineration technology developed in recent ten years. Because of its high combustion heat intensity, it can burn all kinds of fuels which are difficult to ignite or burn out in pulverized coal or chain furnace, such as lean coal, anthracite, coal gangue. At the same time, the incineration of CFB boiler is simple in structure and easy in operation, which is convenient for materials transportation and output. Also, it shows superior performance in temperature measurement and control. For the purpose of achieving clean and efficient utilization of chars, the combustion and emission characteristics of chars are needed to study.

Taking into account the continuity in time as well as the realization of accurate qualified analysis, TG-MS analysis is perhaps the mostly used technique [1], especially in coal/chars combustion. Russell [2] analyzed the combustion reactivity of chars using two thermal analysis instruments TG760 and STA1500 and emphasized on avoiding errors caused by human factors. Shaw et al. [3] found that the reactivity of chars from New Zealand coals of different ranks had obvious differences and combustion temperature of chars from high-rank coals were higher in order to obtain better reactivity. He et al. [4] tested nine different char samples using thermal gravimetric analyzer with continuously rising temperatures and a global one-step kinetic reaction model. Beamish et al. [5] studied the carbon dioxide reactivity of chars from coals of different ranks and found that the lowest rank sub-bituminous coal chars had similar reactivity to lignite coal chars. Arenillas et al. [6] studied the behavior of char combustion by means of TG-MS system and indicated that the heating rate and parent coal rank had a significant influence on the char texture and NO reduction on the char surface. Moreover, they investigated the coal pyrolysis using model compounds and a synthetic coal by TG/MS/FTIR [7] and proved that synthetic coal can be very useful for the study of the reaction mechanisms that involve nitrogen during coal pyrolysis and
This is an Open Access article distributed under the terms of the Creative Commons Attribution Non-Commercial License (http://creativecommons.org/licenses/by-nc/3.0/) which permits unrestricted non-commercial use, distribution, and reproduction in any medium, provided the original work is properly cited.

Copyright (C) 2020 Korean Society of Environmental Engineers
Received May 27, 2019 Accepted August 01, 2019

${ }^{\dagger}$ Corresponding author

Email: gongzhiqiang@upc.edu.cn (Z. Gong), dxl437@sina.com (Z. Wang) Tel: +98-912-425-8802 Fax: +98-218-877-0006 ORCID:0000-0001-5795-257X 
combustion. Gong et al. [8, 9] studied the combustion and NO emission of Shenmu char with a TG-MS system and found that the combustion of Shenmu char was problematic due to late ignition, poor combustion stability, and poor burnout compared with Shenmu coal. Wang et al. [10] used TG/MS/FTIR system to study the pyrolysis of five coals. They pointed out that the evolved gas products during pyrolysis were related to the presence of different functional groups in the coals.

Foreign and domestic scholars had done a lot of work to study the combustion characteristics of chars, but most of the research objectives were chars from high temperature pyrolysis and gasification instead of chars from low-temperature and fast pyrolysis, and researches on the emission characteristics of chars were less. This paper investigated the combustion and emission characteristics of chars from low-temperature and fast pyrolysis of coals of different ranks by means of TG-MS. The results can provide basic data and theoretical support for the combustion of chars in a CFB furnace.

\section{Experiment}

\subsection{Sample Preparation}

Five coals in different ranks were chosen to provide low-temperature and fast pyrolysis chars. The proximate and ultimate analysis of parent coals is shown in Table 1. The parent coals used in the experiment with particle size of $0.5 \mathrm{~mm} \sim 1.0 \mathrm{~mm}$. In the process of industrial analysis and elemental analysis of samples, we grinded the samples and screened them with 80 mesh sieves. Samples with particle size less than $0.2 \mathrm{~mm}$ were prepared for industrial analysis and elemental analysis.

Char samples were prepared in a pyrolysis system, as showed in Fig. 1. The system was composed of furnace, gas distribution system, and sample loading system, temperature control system and cooling system. Our experimental process is as shown in Fig. 2, which used to study the combustion and emission characteristics of coal pyrolysis chars at low temperature. Firstly, we turned on the power of the system and adjusted the temperature to a setting value $\left(600^{\circ} \mathrm{C}\right.$ in this experiment). When the furnace temperature was near $600^{\circ} \mathrm{C}$, we opened $\mathrm{N}_{2}$ cylinder and adjusted flow rate to $8.3 \mathrm{~L} / \mathrm{min}$. Once the temperature was stabled at the setting value and the furnace was filled with $\mathrm{N}_{2}$, the push rod with crucibles loading samples could be pushed to the heating zone quickly. $10 \mathrm{~min}$ later, we pushed the rod to the cooling zone until it reached at room temperature. At last, char samples were collected and sieved into diameter of $0.50-0.71 \mathrm{~mm}$, and placed in a drying container to save. The char sample from SGY coal pyrolysed at $600^{\circ} \mathrm{C}$ was marked as SGY-Char, so were the other char samples.

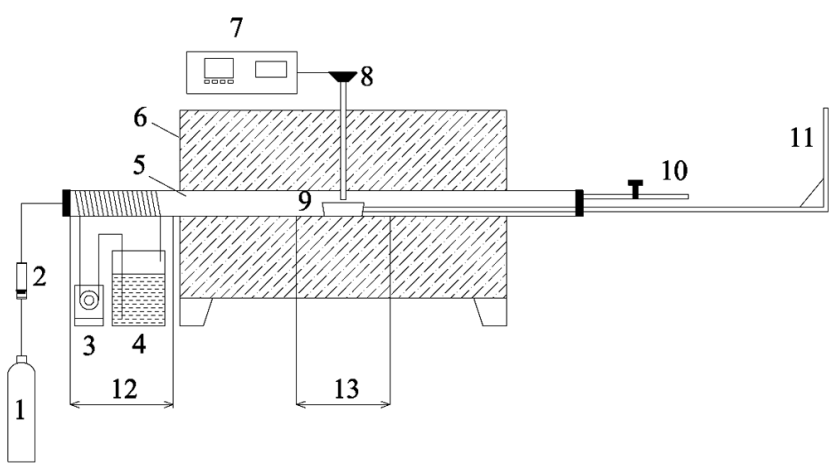

Fig. 1. Schematic diagram of the pyrolysis system.

1- $\mathrm{N}_{2}$, 2-Flowmeter, 3-Water pump, 4-Water tank, 5-Reactor, 6-Electric furnace, 7-Temperature controller, 8-Thermocouple, 9-Crucible, 10-Exhaust pipe, 11-Push rod, 12-Cooling zone, 13-Heating zone.

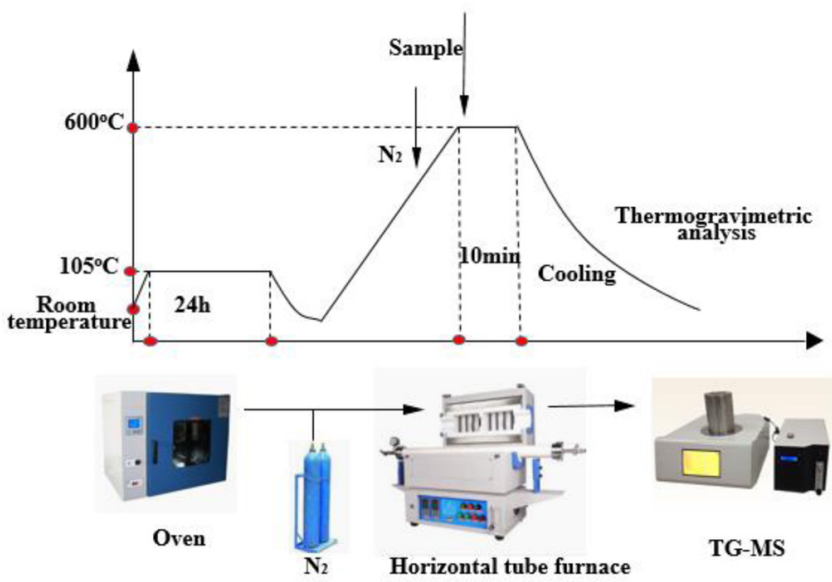

Fig. 2. Schematic diagram of the pyrolysis system.

Table 1. Proximate and Ultimate Analysis of Parent Coals

\begin{tabular}{|c|c|c|c|c|c|c|c|c|c|c|c|}
\hline \multirow{2}{*}{ Samples } & \multirow{2}{*}{ Rank } & \multicolumn{4}{|c|}{ Proximate analysis } & \multicolumn{6}{|c|}{ Ultimate analysis } \\
\hline & & $M_{\text {ar }} \%$ & $A_{\mathrm{ad}} \%$ & $V_{\text {daf }} \%$ & $F C_{\text {ad }} \%$ & $\mathrm{C}_{\mathrm{ad}} \%$ & $\mathrm{H}_{\mathrm{ad}} \%$ & $\mathrm{O}_{\mathrm{ad}} \%$ & $\mathrm{~N}_{\mathrm{ad}} \%$ & $\mathrm{~S}_{\mathrm{ad}} \%$ & $Q_{\text {ad,net }} \mathbf{k J} / \mathbf{k g}$ \\
\hline SGY & lignite & 13.00 & 24.71 & 39.76 & 43.10 & 55.46 & 3.42 & 9.96 & 0.72 & 1.99 & 21460 \\
\hline YNI & lignite & 3.40 & 52.51 & 35.31 & 29.99 & 35.26 & 2.23 & 7.52 & 0.67 & 0.68 & 13410 \\
\hline YNII & lignite & 37.80 & 8.10 & 45.53 & 38.48 & 51.61 & 3.10 & 14.46 & 0.95 & 0.52 & 19160 \\
\hline SM & sub-bituminous & 7.27 & 8.54 & 35.49 & 57.13 & 71.16 & 4.12 & 12.02 & 0.92 & 0.34 & 27021 \\
\hline FJ & anthracite & 9.70 & 17.10 & 3.52 & 70.70 & 69.42 & 0.35 & 2.87 & 0.22 & 0.42 & 23590 \\
\hline
\end{tabular}

ar is as recieved basis

ad is air dry basis air dry basis

daf is dry and ash free basis 


\subsection{Method}

The combustion and emission characteristics of prepared char samples were analyzed using the TG-MS system, including the STA449F3 NETZSCH thermal analyzer and the QMS403C Aeolos type quadrupole mass spectrometer. To start the experiment, samples of about $10 \mathrm{mg}$ was tiled at the bottom of an $\mathrm{Al}_{2} \mathrm{O}_{3}$ crucible and the internal atmosphere of TGA was set to the air atmosphere, which was composed of $21 \mathrm{~mL} / \mathrm{min}$ of oxygen and $79 \mathrm{~mL} / \mathrm{min}$ of nitrogen. The sample was heated from $40^{\circ} \mathrm{C}$ to $1,000^{\circ} \mathrm{C}$ with a heating rate of $20^{\circ} \mathrm{C} / \mathrm{min}$. After the TGA test, the gases products entered into the mass spectrometer for detection and analysis. In this paper, we mainly focused on the behaviors of nitrogen and sulfur compounds during coal and char combustion.

\section{Results}

\subsection{TG and DTG Results}

The TG and DTG profiles of char samples and its parent coal are represented in Fig. 3 and Fig. 4. The TG profiles show that there are at least two weight losses for all the samples. The first weight loss was from loss of the moisture and the second or third weight loss was from the combustion of coal or carbon residue. The final weight loss was proportional to the ash content of samples. The DTG profiles of YNI coal, YNI-Char, YNII coal and YNII-Char had two peaks while the others had only one peak. Compared with parent coal, the maximum weight loss peak appeared at higher temperature. Coal contained larger amounts of volatile, and heat from combustion of the volatile could accelerate the temperature rise around coal particles. Furthermore, volatile releasing could help develop pore structure in a short time, so coal could be in good contact with the oxidant at high temperatures, which was very favorable for combustion.

The summary of the TG/DTG results for all the samples are given in Table 2. The temperature of maximum weight loss of char samples $\left(T_{\max }\right)$ was higher than its parent coal as shown in Table 2. Besides, the maximum rate of weight loss, the average rate of weight loss as well as the final weight loss of char samples

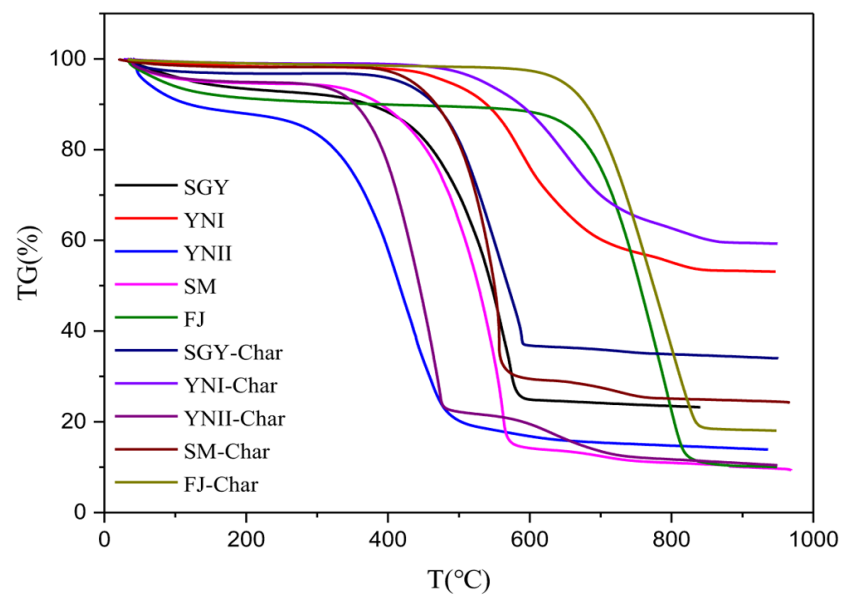

Fig. 3. TG profiles of coal and char samples.

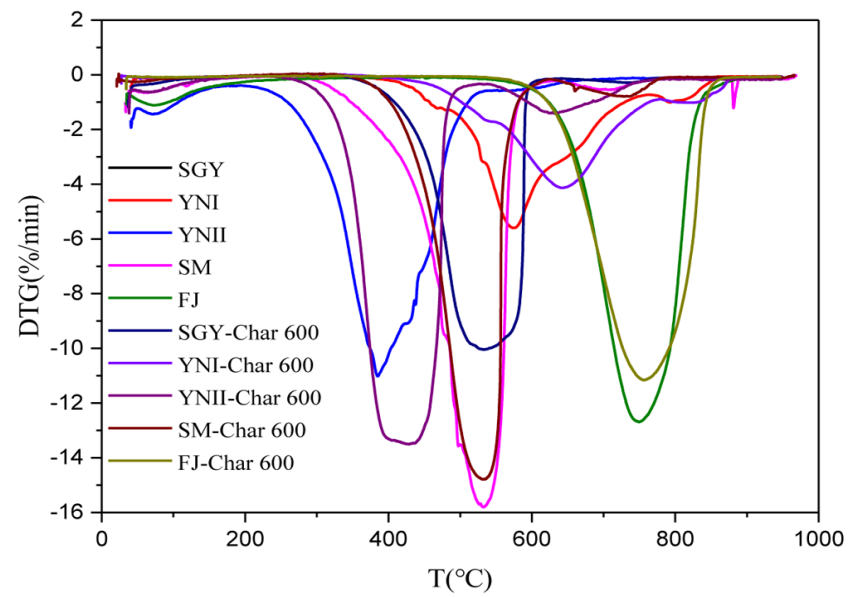

Fig. 4. DTG profiles of coal and char samples.

Table 2. Summary of TG and DTG Results

\begin{tabular}{lcccc}
\hline \multirow{2}{*}{ Sample } & $\boldsymbol{T}_{\max }$ & $(\boldsymbol{d} \boldsymbol{w} / \boldsymbol{d} \boldsymbol{\tau})_{\max }$ & $(\boldsymbol{d} \boldsymbol{w} / \boldsymbol{d} \tau)_{\text {mean }}$ & $\boldsymbol{W}_{\text {loss }}$ \\
\cline { 2 - 5 } SGY & ${ }^{\circ} \mathbf{C}$ & $\boldsymbol{\%} / \mathbf{m i n}$ & $\boldsymbol{\%} / \mathbf{m i n}$ & $\boldsymbol{\%}$ \\
SGY-Char & 525.34 & 10.08 & 1.77 & 76.80 \\
YNI & 532.99 & 10.05 & 1.35 & 66.02 \\
YNI-Char & 573.75 & 5.60 & 0.96 & 46.89 \\
YNII & 344.26 & 4.13 & 0.83 & 40.72 \\
YNII-Char & 428.06 & 15.51 & 1.78 & 86.11 \\
SM & 540.19 & 14.62 & 1.83 & 89.57 \\
SM-Char & 555.00 & 11.13 & 1.94 & 90.65 \\
FJ & 749.49 & 12.70 & 1.84 & 89.96 \\
FJ-Char & 755.93 & 11.17 & 1.67 & 81.95 \\
\hline
\end{tabular}

$T_{\max }$ is the temperature of maximum weight loss.

$(d w / d \tau)_{\max }$ is the maximum rate of weight loss.

$(d w / d \tau)_{\text {mean }}$ is the average rate of weight loss.

$W_{\text {loss }}$ is the final weight loss.

were larger except for YNII-Char. The YNII coal had a high content of volatile and moisture. Its moisture content was $37.80 \%$, which made YNII coal hard to ignite and combust in CFB. YNII-Char had little moisture after pyrolysis and still contained a certain amount of volatile. In a word, the combustion characteristic of char from low-temperature and fast pyrolysis was poorer than its coal in most cases regardless of the level of coal ranks.

\subsection{MS Results}

The profiles of nitrogen containing and sulfur containing gaseous products of the samples are represented in Fig. 5 and Fig. 7. As can be seen from the figure, the temperature range of releasing of gaseous product had a good agreement with that of TGA weight loss. Gaseous products of samples with high content of volatile were released earlier than samples with relatively low content of volatile. Therefore, gaseous products during combustion of char samples were observed at higher temperature than parent coals, 

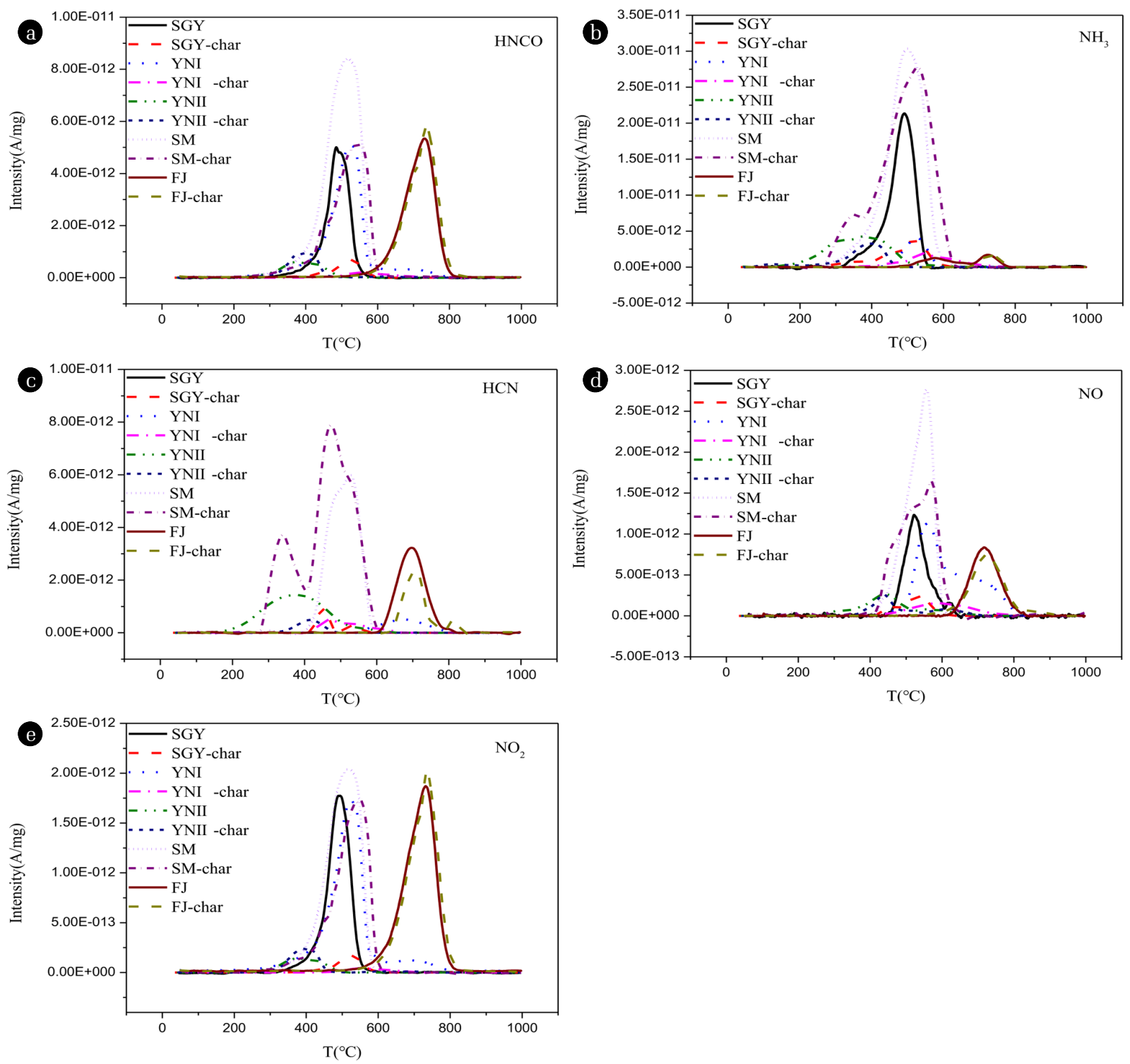

Fig. 5. Nitrogen gases release profiles. (a) $\mathrm{HNCO}$ release profile, (b) $\mathrm{NH}_{3}$ release profiles, (c) $\mathrm{HCN}$ release profiles, (d) $\mathrm{NO}$ release profiles, (e) $\mathrm{NO}_{2}$ release profiles.

and for high rank coal, FJ, with a volatile content of $3.52 \%$, gaseous products were not found until $600^{\circ} \mathrm{C}$, while gases of other coal samples had all been released before $600^{\circ} \mathrm{C}$. The Char samples had the same trend as parent coals. Peak temperatures and initial gas release temperatures for different samples are shown in the attached Table S1 and Table S2, respectively.

Fig. 5(a) shows that the HNCO release profiles of all the samples have a peak, it can be seen that the SM, YNI, SGY, YNII, YNII-Char and SM-Char had the lowest HNCO release temperature, which were about $250^{\circ} \mathrm{C}-300^{\circ} \mathrm{C}$. As for the peak temperatures of HNCO release curves of samples, the common char had a higher peak temperature than its parent coal and the FJ and FJ char had the highest peak temperatures, which were about $700^{\circ} \mathrm{C}$. For the release amount of HNCO, SM released the highest amount of HNCO.
Researchers [11-13] found that HNCO was one of the primary intermediate products of coal pyrolysis after studying on pyrolysis of coal and nitrogen-containing model compounds. They believed that the $\mathrm{HCN}$ and $\mathrm{NH}_{3}$ may be produced by $\mathrm{HNCO}$ after a series of reactions. In CFB boiler, HNCO released from pyrolysis would quickly decompose into NCO in the combustion chamber [14-16], while Miller [17] found that the reaction between NCO and NO reaction was the main source for $\mathrm{N}_{2} \mathrm{O}$. Therefore, $\mathrm{HNCO}$ may be one of the main precursors of $\mathrm{N}_{2} \mathrm{O}$ under fluidized bed combustion.

It can be seen that it appears two peaks in $\mathrm{NH}_{3}$ release profiles of some samples from Fig. 5(b). The first peak occurred between $300^{\circ} \mathrm{C}-400^{\circ} \mathrm{C}$ and the second one occurred between $500^{\circ} \mathrm{C}-600^{\circ} \mathrm{C}$. While for FJ coal and FJ-Char, it occurred after $700^{\circ} \mathrm{C}$ as their weight losses happened at higher temperature than other samples 
in TG experiment. For the release amount of $\mathrm{NH}_{3}$, the SM, SM-Char and SGY released the highest amount of $\mathrm{NH}_{3}$. Fig. 5(c) shows $\mathrm{HCN}$ release profiles of all the samples. HCN was not detected during combustion of SGY coal, but there were two peaks in HCN release profile for SGY-Char. The first peak occurred at $400^{\circ} \mathrm{C}-500^{\circ} \mathrm{C}$, and the second peak occurred between $500^{\circ} \mathrm{C}-600^{\circ} \mathrm{C}$ except for FJ coal and FJ-Char. The HCN release profiles for other samples were similar to $\mathrm{NH}_{3}$. $\mathrm{HCN}$ and $\mathrm{NH}_{3}$ were considered as the main precursors of $\mathrm{NO}_{\mathrm{x}}$ during coal combustion [18-21].

The $\mathrm{NO}$ and $\mathrm{NO}_{2}$ release profiles of all the samples are represented in Fig. 5(d) and (e). There was one peak in the profiles. The release temperature was in agreement with nitrogen containing gases above. The peak height and size of integral area of profiles can reveal the relative value of gaseous release. It could be seen that the SGY, SGY-Char, YNI, YNI-Char, YNII, YNII-Char, SM and SM-Char had the lowest NO release temperature, which was about $300^{\circ} \mathrm{C}-400^{\circ} \mathrm{C}$, and the FJ and FJ-Char had the highest release temperature of about $600^{\circ} \mathrm{C}$. As for the peak temperatures of $\mathrm{NO}$, the YNII and YNII-Char had the lowest peak temperature of about $350^{\circ} \mathrm{C}-400^{\circ} \mathrm{C}$ while the FJ and FJ char had the highest peak temperatures of about $700^{\circ} \mathrm{C}$. For the release amount of NO, the SM released the highest amount of NO. It can be seen that the YNII, YNII-Char, SM, SGY, SM Char and YNI had the lowest $\mathrm{NO}_{2}$ release temperature, which was about $300^{\circ} \mathrm{C}$. As for the peak temperatures of $\mathrm{NO}_{2}$ release curves, the YNII and YNII-Char had the lowest peak temperature of about $350^{\circ} \mathrm{C}-400^{\circ} \mathrm{C}$ while the FJ and FJ char had the highest peak temperatures of about $730^{\circ} \mathrm{C}$. For the released amount of $\mathrm{NO}_{2}$, the $\mathrm{SM}$ releases the highest amount of $\mathrm{NO}_{2}$.

As can be seen, char samples had less volatile- $\mathrm{N}$ after fast pyrolysis, so the $\mathrm{NO}$ and $\mathrm{NO}_{2}$ emissions were lower than parent coals. Coals of high rank of anthracite and sub-bituminous released more $\mathrm{NO}$ and $\mathrm{NO}_{2}$ than low rank coals of lignite, so were chars from coals of different ranks. The behavior of nitrogen compounds in coal combustion is shown in Fig. 6.

As is shown in Fig. 7(a), $\mathrm{H}_{2} \mathrm{~S}$ was mainly released at $300^{\circ} \mathrm{C}-800^{\circ} \mathrm{C}$, and only one peak occurred at about $500^{\circ} \mathrm{C}-600^{\circ} \mathrm{C}$ and $710^{\circ} \mathrm{C}$ for different samples. It can be seen from the profile area that the SGY, SM-Char, YNI, FJ and FJ-Char released a higher amount of $\mathrm{H}_{2} \mathrm{~S} . \mathrm{H}_{2} \mathrm{~S}$ released during coal combustion mainly came from the decomposition of pyrite and aliphatic sulfur. The origin of $\mathrm{H}_{2} \mathrm{~S}$ evolution below $500^{\circ} \mathrm{C}$ was aliphatic sulfur while at $580^{\circ} \mathrm{C}, \mathrm{H}_{2} \mathrm{~S}$ mainly came from the decomposition of pyrite [25, 26]. When temperature was $600^{\circ} \mathrm{C}$ higher, the $\mathrm{H}_{2} \mathrm{~S}$ was mainly from decomposition organic sulfur with strong bonding. Most sulfurs in samples existed as aliphatic functional groups except for FJ coal and FJ-Char, the sulfur of which mainly came from pyrite.

We can see that COS is not observed during the combustion of SGY-Char, YNII coal, SM coal, FJ coal and FJ-Char from Fig. 7 (b). It can be seen from the profile area that the SGY released the largest amount of COS. Researchers [27, 28] pointed out that COS mainly came from reactions between $\mathrm{CO}$ and elemental sulfur or pyrite. As we motioned above, the sulfurs in most samples were existing as aliphatic functional groups rather than pyrite, so COS was not observed during combustion of all the samples.

The $\mathrm{SO}_{2}$ release profiles of all the samples are represented in Fig. 7(c). It can be seen that the FJ and FJ-Char had the lowest $\mathrm{SO}_{2}$ release temperature, which was about $600^{\circ} \mathrm{C}$. As for the peak

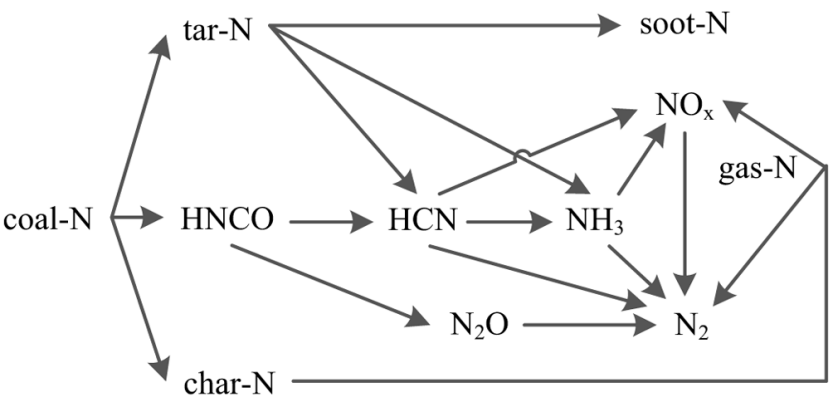

Fig. 6. Behavior of nitrogen compounds in coal combustion [22-24].
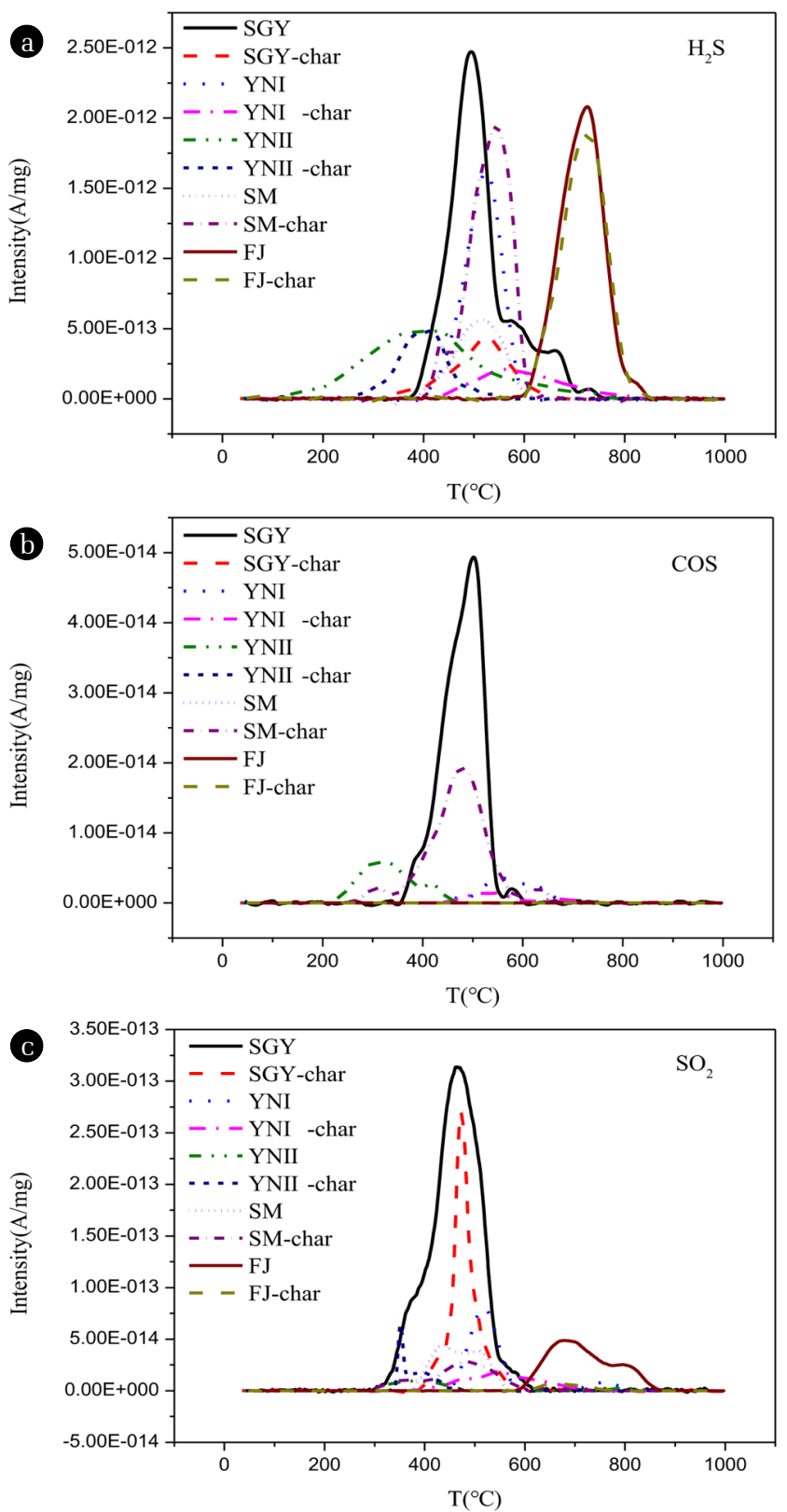

Fig. 7. Sulfur-containing gases release profiles. (a) $\mathrm{H}_{2} \mathrm{~S}$ release profiles, (b) $\mathrm{COS}$ release profiles, (c) $\mathrm{SO}_{2}$ release profiles. 


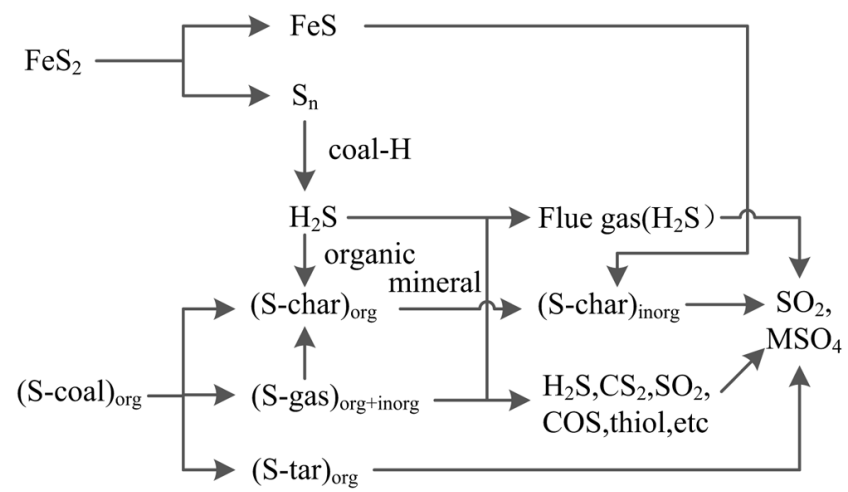

Fig. 8. Behavior of sulfur compounds in coal combustion.

temperatures of $\mathrm{SO}_{2}$, the SGY had the highest peak temperature of about $1,000^{\circ} \mathrm{C}$. The profile area shows that the SGY and SGY-Char released a higher amount of $\mathrm{SO}_{2} . \mathrm{SO}_{2}$ released before $450^{\circ} \mathrm{C}$ mainly came from unstable aliphatic and aromatic sulfur while above $550^{\circ} \mathrm{C}$ $\mathrm{SO}_{2}$ came from the oxidation of pyrite [29-31]. At higher temperatures, sulfate would be decomposed to produce $\mathrm{SO}_{2}$, while the sulfone compounds also produced $\mathrm{SO}_{2}$ during pyrolysis, but coal had little content of sulfone. As can be seen, $\mathrm{SO}_{2}$ emissions of char samples were lower than parent coals. However, $\mathrm{SO}_{2}$ emission did not show an obvious relationship with coal rank. The behavior of sulfur compounds in coal combustion is shown in Fig. 8.

\section{Conclusions}

The combustion and pollutant emission characteristics of chars from low-temperature and fast pyrolysis in a horizontal tube furnace were studied in a TG-MS analyzer. The conclusions are as follows:

(1) In most cases, the low-temperature and fast pyrolysis coals had higher ignition temperature and maximum weight loss temperature, thus its combustion characteristics was poor than its parent coals regardless of the level of coal ranks.

(2) The temperature range of gaseous product releasing had a good agreement with that of TGA weight loss, and the weight loss of the sample was mainly caused by the release of volatiles in the sample.

(3) The gas products of chars in the combustion process were observed at a higher temperature than the parent coal, mainly because the low-temperature and fast pyrolysis chars had a lower content of volatile than that of parent coal.

(4) The $\mathrm{NO}$ and $\mathrm{NO}_{2}$ emissions of chars were lower than parent coals. Coals of high rank of anthracite and sub-bituminous released more $\mathrm{NO}$ and $\mathrm{NO}_{2}$ than low rank coals of lignite, so were chars from coals of different ranks. $\mathrm{SO}_{2}$ emissions of char samples were lower than parent coals and did not show obvious relationship with coal ranks.

\section{Acknowledgment}

The research was supported by the Natural Science Foundation of Shandong Province (No. ZR2017BEE042) and the Talent
Introduction Project of China University of Petroleum (East China), No. 2017010068, China University of Petroleum (East China) Postgraduate Innovation Project, NO YCX2019047.

\section{Reference}

1. Wang M, Li Z, Huang W, Yang J, Xue H. Coal pyrolysis characteristics by TG-MS and its late gas generation potential. Fuel 2015;156:243-253.

2. Russell NV, Beeley TJ, Man CK, Gibbins JR, Williamson J. Development of TG measurements of intrinsic char combustion reactivity for industrial and research purposes. Fuel Proc. Technol. 1998;57:113-130.

3. Shaw KJ, Beamish BB, Rodgers KA. Thermogravimetric analytical procedures for determining reactivities of chars from New Zealand coals. Thermochim. Acta. 1997;302:181-187.

4. Rong H, Sato JI, Chen Q, Chen C. Thermogravimetric analysis of char combustion. Combust. Sci. Technol. 2002;174:1-18.

5. Basil BB, Shaw KJ, Rodgers KA, Newman J. Thermogravimetric determination of the carbon dioxide reactivity of char from some New Zealand coals and its association with the inorganic geochemistry of the parent coal. Fuel Proc. Technol. 1998;53:243-253.

6. Arenillas A, Rubiera F, Pis JJ, Jones JM, Williams A. The effect of the textural properties of bituminous coal chars on NO emissions. Fuel 1999;78:1779-1785.

7. Arenillas A, Pevida C, Rubiera F, GarcíA R, Pis JJ. Characterisation of model compounds and a synthetic coal by TG/MS/FTIR to represent the pyrolysis behaviour of coal. J. Anal. Appl. Pyrol. 2004;71:747-763.

8. Gong Z, Liu Z, Zhou T, Lu Q, Sun Y. Combustion and NO emission of Shenmu Char in a $2 \mathrm{MW}$ circulating fluidized bed. Energ. Fuels 2015;29:1219-1226.

9. Gong Z, Xia H, Liu Z, Lu Q. TG-MS Study on Coal/Char combustion by equivalent characteristic spectrum analysis. In: Clean Coal Technology and Sustainable Development. Berlin: Springer; 2015.

10. Wang S, Tang Y, Schobert HH, Guo Yn, Gao W, Lu X. FTIR and simultaneous TG/MS/FTIR study of late permian coals from Southern China. J. Anal. Appl. Pyrol. 2013;100:75-80.

11. Zou C, Wu H, Zhao J, Li X. Effects of dust collection from converter steelmaking process on combustion characteristics of pulverized coal. Powder Technol. 2018;332:70-78.

12. Zhao Z, Wang R, Ge L, Wu J, Yin Q, Wang C. Energy utilization of coal-coking wastes via coal slurry preparation: The characteristics of slurrying, combustion, and pollutant emission. Energy 2019;168:609-618.

13. Mehmood MA, Ahmad MS, Liu Q, et al. Helianthus tuberosus as a promising feedstock for bioenergy and chemicals appraised through pyrolysis, kinetics, and TG-FTIR-MS based study. Energ. Convers. Manage. 2019;194:37-45.

14. Lu C, Wang X, Li R, et al. Emissions of fine particulate nitrated phenols from residential coal combustion in China. Atmos. Environ. 2019;203:10-17.

15. Hu G, Liu G, Wu D, Fu B. Geochemical behavior of hazardous volatile elements in coals with different geological origin during 
combustion. Fuel 2018;233:361-376.

16. Oliveira MLS, Boit KD, Pacheco F, et al. Multifaceted processes controlling the distribution of hazardous compounds in the spontaneous combustion of coal and the effect of these compounds on human health. Environ. Res. 2018;160:562.

17. Liu Z, Wang G, Li P, Li C. Investigation on combustion of high-sulfur coal catalyzed with industrial waste slags. J. Energ. Inst. 2019;92:621-629.

18. Li Z, Jiang L, Ouyang J, Cao L, Luo G, Yao H. A kinetic study on char oxidation in mixtures of O2, $\mathrm{CO} 2$ and H2O. Fuel Proc. Technol. 2018;179:250-257.

19. Wang L, Su S, Qing M, et al. Melting solidification and leaching behaviors of V/As during co-combustion of the spent SCR catalyst with coal. Fuel 2019;252:164-171.

20. Guo F, Zhong Z. Optimization of the co-combustion of coal and composite biomass pellets. J. Clean. Prod. 2018;185:399-407.

21. Jiang Y, Zong P, Tian B, et al. Pyrolysis behaviors and product distribution of Shenmu coal at high heating rate: A study using TG-FTIR and Py-GC/MS. Energ. Convers. Manage. 2019;179: 72-80.

22. Salema AA, Ting RMW, Shang YK. Pyrolysis of blend (oil palm biomass and sawdust) biomass using TG-MS. Bioresour. Technol. 2019;274:439-446.

23. Zhu Y, Wen W, Li Y, et al. Pyrolysis study of Huainan coal with different particle sizes using TG analysis and online Py-PI-TOF MS. J. Energ. Inst. 2019.
24. Jayaraman K, Kok MV, Gokalp I. Pyrolysis, combustion and gasification studies of different sized coal particles using TGA-MS. Appl. Therm. Eng. 2017;125:1446-1455.

25. Fang P, Gong Z, Wang Z, Wang Z, Meng F. Study on combustion and emission characteristics of microalgae and its extraction residue with TG-MS. Renew. Energ. 2019;140:884-894.

26. Lin Y, Liao Y, Yu Z, Fang S, Ma X. A study on co-pyrolysis of bagasse and sewage sludge using TG-FTIR and Py-GC/MS. Energ. Convers.Manage. 2017;151:190-198.

27. Li R, Chen Q, Xia H. Study on pyrolysis characteristics of pretreated high-sodium (Na) Zhundong coal by skimmer-type interfaced TG-DTA-EI/PI-MS system. Fuel Proc. Technol. 2018;170:79-87.

28. Gong Z, Wang Z, Wang Z, Fang P, Meng F. Study on the migration characteristics of nitrogen and sulfur during co-combustion of oil sludge char and microalgae residue. Fuel 2019;238:1-9.

29. Wang Z, Gong Z, Wang Z, Fang P, Han D. A TG-MS study on the coupled pyrolysis and combustion of oil sludge. Thermochim. Acta. 2018;663:137-144.

30. Luo L, Liu J, Zhang H, Ma J, Wang X, Jiang X. TG-MS-FTIR study on pyrolysis behavior of superfine pulverized coal. $J$. Anal. Appl. Pyrol. 2017;128:64-74.

31. Jayaraman K, Kok MV, Gokalp I. Thermogravimetric and mass spectrometric (TG-MS) analysis and kinetics of coal-biomass blends. Renew. Energ. 2017;101:293-300. 